Open Access

Research Article
Res. Agric. Livest. Fish. Vol. 2, No. 3, December 2015: 491-497

\title{
IMPACT OF FIFTEEN DAYS FISHING BAN IN THE MAJOR SPAWNING GROUNDS OF HILSA (Tenualosa ilisha HAMILTON 1822) ON ITS SPAWNING SUCCESS
}

\section{Md. Anisur Rahman, Flura*, Tayfa Ahmed, Md. Mehedi Hasan Pramanik and Mohammad Ashraful Alam}

Bangladesh Fisheries Research Institute, Riverine Station, Chandpur-3602, Bangladesh

*Corresponding author: Flura; E-mail: flura_bfri@yahoo.com

\begin{tabular}{|c|c|}
\hline ARTICLE INFO & ABSTRACT \\
\hline $\begin{array}{l}\text { Received } \\
30.11 .2015 \\
\text { Accepted } \\
09.12 .2015 \\
\text { Online } \\
21.12 .2015 \\
\text { Key words } \\
\text { Impact } \\
\text { Hilsa } \\
\text { Spawning } \\
\text { Ban }\end{array}$ & $\begin{array}{l}\text { The present study was conducted to assess the impact of fifteen days fishing ban on } \\
\text { breeding success of hilsa shad in the major spawning grounds of hilsa in the month of } \\
\text { September and October, } 2015 \text {. The study showed that fishing ban during spawning seasons } \\
\text { have significant role in the successful reproduction of hilsa. In and around the spawning } \\
\text { grounds among all the captured hilsa, male: female ratio was found } 1: 1.86 \text { and percent } \\
\text { composition was } 35 \% \text { and } 65 \% \text { respectively. In } 2015 \text {, percent composition of spent hilsa } \\
\text { during major breeding period in the spawning grounds was found } 36.60 \% \text {. The eggs } \\
\text { production of hilsa was calculated, in the year } 2010,2011,2012,2013,2014 \text { and } 2015 \\
\text { about } 336199 \mathrm{Kg} \text {, } 385500 \mathrm{Kg}, 380400 \mathrm{Kg} \text {, } 447100 \mathrm{Kg}, 417765 \mathrm{Kg} \text { and } 494365 \mathrm{Kg} \text { respectively, } \\
\text { hilsa eggs could have been produced indicating a positive impact of } 15 \text { days fishing ban in } \\
\text { the spawning season. Comparatively higher percentages of gravid hilsa were found which } \\
\text { were not available in the similar quantity and condition in the fishing ban period in other } \\
\text { than spawning areas of hilsa. During the present investigation, fairly higher amount of spent } \\
\text { hilsa and juveniles were observed in the spawning grounds. On the other hand, fewer } \\
\text { juveniles and spent hilsa were observed in the adjacent areas of the spawning grounds } \\
\text { indicating that in comparison to the recent reports there might have little or no changes of } \\
\text { the spawning grounds of hilsa occurred. Along with the jatka fry, spawn and fries of other } \\
\text { fishes were also found in higher quantity than the previous years and thus it is assumed that } \\
15 \text { days fishing ban also might have positive impact on the successful breeding of other } \\
\text { fishes. Overall, the fishing ban was found effective for successful breeding of hilsa. }\end{array}$ \\
\hline
\end{tabular}

To cite this article: Rahman MA, Flura, T Ahmed, MMH Pramanik and MA Alam, 2015. Impact of fifteen days fishing ban in the major spawning grounds of hilsa (Tenualosa ilisha Hamilton 1822) on its spawning success. Res. Agric. Livest. Fish. 2 (3): 491-497.

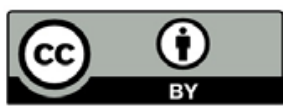

This is an open access article licensed under the terms of the Creative Commons Attribution 4.0 International License

www.agroaid-bd.org/ralf, E-mail: editor.ralf@gmail.com 


\section{INTRODUCTION}

The hilsa shad, commonly known as Hilsa (Tenualosa ilisha, Hamilton 1822) referred in the literature as an anadromous (earlier) Clupeid of the Bay of Bengal and Indian Ocean, now established as a diadromous ascends in the rivers flowing into the Bay of Bengal, Arabian Sea and Persian Gulf. Hilsa belongs to the subfamily Alosinae, family Clupeidae, order Clupeiformes, and is one of the most important tropical fishes of the Indo-Pacific region. It is a fast swimming euryhaline known for its cosmopolitan distribution in brackish water estuaries and marine environment. Naturally hilsa is in great demand globally, specifically in the oriental world and enjoys high consumer preference. Its high commercial demand makes it a good forex earner. This is an important migratory species in the Indo-Pak sub-continent, especially in Bangladesh, India and Myanmar. Tenualosa ilisha (Fisher and Bianchi, 1984) is the most widespread tropical shads found from north Sumatra in the east to Kuwait in the west and is the basis of important fisheries in Bangladesh, India, Burma, Pakistan and Kuwait (Al-baz and Grove, 1995; Whitehead, 1985; Blaber, 2000). It is the national fish of Bangladesh and the largest single species fishery contributing $75 \%$ of total catch in this region (Raja, 1985) that accounts nearly half of the total marine catch and about $12-13 \%$ of total fish production of the country (Haldar, 2008).

\section{Impact of fifteen days fishing ban}

The hilsa fishery was declining tremendously over the last decades for increasing fishing pressure and environmental degradation from the inland open water although the total marine production remains more or less static. In an investigation, Haldar and Rahman (1998) found that hilsa landing at Chandpur (a major landing center) has lost about $25.8 \%$ from $1978-88$ to $1989-94$ due to loss of freshwater discharge from the upstream international river. Construction of cross dam and flood control dam has destroyed a commercial hilsa fishery of about $500 \mathrm{MT} / \mathrm{yr}$ (Haldar et al., 1992). In addition, during the spawning migration (marine water to freshwater and vice versa) large numbers of gravid and immature fishes are being caught using various destructive fishing gears. That is why; the hilsa fishery in Bangladesh has been suffered by a combination of factors viz. serious recruitment over-fishing (indiscriminate harvest of gravid fishes) and growth over-fishing (indiscriminate catching of jatka). In these circumstances, considering the importance of hilsa in nutrition, employment and economy, the Hilsa Fishery Management Action Plan (HFMAP) was prepared for the development, management and conservation of hilsa incorporating the objectives of protection of nursery and breeding grounds and banning capture of hilsa indiscriminately. Hilsa is caught and landed throughout the year; the majority of landing $(60-70 \%)$ is found during the peak breeding season (September-October). In this season, about $60-70 \%$ hilsa are found to be sexually mature and ripe. At least $30 \%$ of the population appears to be ripening at any time in most areas.

Five sites in the coastal areas of the country have been declared as hilsa sanctuaries under the 'Protection and conservation of fish Act-1950 for the effective conservation of jatka in the major nursery areas and maintenance of fish biodiversity viz, 1. From Shatnol of Chandpur district to char Alexander of Laxmipur (1000 km of lower Meghna estuary) 2. Madanpur/Char Illisha to Char Pial in Bhola district (90 km area of Shahbajpur river, a tributary of the Meghna river). 3. Bheduria of Bhola district to Char Rustam of Potuakhali district (nearly $100 \mathrm{~km}$ area of Tetulia river). 4. Whole $40 \mathrm{~km}$ stretch of Andharmanik river in kalapara Upazila of Potuakhali district and 5. Lower Padma river at Shariatpur district, $20 \mathrm{~km}$ stretch of Padma river. It has been identified that the highest number of ripe and running hilsa are being caught indiscriminately during five days before and nine days after the full moon including the full moon day altogether of September-October every year during their peak spawning time and thus their recruitment was being hampered. Hence, fishing ban is required for certain time specification for their successful breeding. In the above context, Government has enacted a new rule under the Protection and Conservation of Fish Act, 1950 banning the hilsa catch during this period for successful spawning. The rule is being implemented by Department of Fisheries (DoF) from the year of 2007 involving different stakeholders and law enforcing agencies including Navy and Coast Guards. 


\section{MATERIALS AND METHODS}

The hilsa investigation team of the Riverine Station, Chandpur carried out the investigations. Modernized research vessel and speed boat were utilized for sampling and data collection. Major spawning grounds of hilsa and related areas viz, Chandpur, Ramgoti, Hatia, Dhalchar, Moulovirchar, Monpura, Kalirchar, Daulatkhan, Barisal, Bhola, Patharghata, Potuakhali, Mohipur, Galachipa, Kalapara were visited for comprehensive study. To determine the size of group, captured hilsa from the above mentioned area were calculated by measuring scale. Sex was determined by external observation, gentle stripping at their belly along the ventral scute line from anterior to anal direction with the fore and first finger together was applied. While at stripping along the belly, white milky or creamy liquid for the male and eggs with blood strain or food particle for the female usually came out through the anus. Seeing the milky/creamy liquid (the milt) and the eggs, hilsa was identified as male or female. When such milky liquid or eggs do not come out, and then the fish is either of immature or premature stage. The potbellied, reddish and bigger anus also identified the fishes as female. As such, the percent composition of gravid and oozing hilsa was determined (Rahman et al., 2013). The spent fishes were identified by observing their very lean and thin and elongated body and health condition and shrunken belly. While stripping at their belly, isolated and distorted eggs came out with watery liquid or with or without blood strain. The hilsa are the gonochoristic (Blaber et al., 2001) and single shedding fishes (Haldar, 2004). After shedding usually they do not die, locally called Pite (spent) fishes and are caught with other hilsa. The number and percent of spent fishes was determined by observing the catches of the commercial fishermen in and around the spawning grounds immediate before and after the 15 days ban period. The amount of fertilized egg production in the spawning grounds due to fishing ban as an indicator of spawning success was estimated using the following formula.

Total No. of Hilsa excluded due to fishing ban $(T N)=$ No. of fishing boat $\times$ Haul/day $\times$ Fish

Caught/Haul $\times$ No. of days

Total fertilized eggs $(\mathrm{Kg})=\underline{\mathrm{TN} \times \mathrm{FF} \times \mathrm{SF} \times \mathrm{EF}}$

Where, $\mathrm{TN}=$ Total No. of Hilsa excluded due to fishing ban;

$\mathrm{FF}=\%$ of female fishes in the study area;

$\mathrm{SF}=\%$ of spent Fish, and

$\mathrm{EF}=$ Average egg $(\mathrm{g})$ per fish.

Experimental egg/fry collection was done by a 'savar net' (shrimp PL collecting net) prepared by fine meshed glass nylon in the spawning grounds and adjacent areas to observe abundance and distribution of jatka. Finally, by the availability of immature and oozing hilsa statement about the previously identified spawning grounds were made.

\section{RESULTS AND DISCUSSION}

\section{Size, sex and percent composition of berried hilsa}

During the river cruise gradually larger sized hilsa were found from Chandpur to the downstream. In the upper region, most of the hilsa found were below $35 \mathrm{~cm}$, whereas, more than $85 \%$ hilsa were above $35 \mathrm{~cm}$ in the downstream areas. In and around the spawning grounds among all the captured hilsa, male: female ratio was $1: 1.86$ and percent composition was $35 \%$ and $65 \%$ respectively. Haldar (2004) also found male-female ratio almost 1:2 during the study period. Although, there are conflicting views about the sex ratio of hilsa in earlier studies, (Islam et al., 1987) found no significant difference of male-female ratio at four important landing centers viz Chittagong (1:1.04); Chandpur (1:1.08); Khepupara (1:0.8) and except Cox's Bazar (1:1.8). Similar observations were also made by (Shafi et al., 1976) in respect of Padma and Meghna river hilsa. Quereshi (1968) observed the sex ratio was 1:1 during the monsoon, but female was dominated in October. Blaber et al., (2001) indicated that here is a bias in sex ratio and the male are more abundant among the smaller fishes. Rahman et al., 2013 found the majority of fishes over $32 \mathrm{~cm}$ are females and almost all over $38 \mathrm{~cm}$ and males are predominant between 10 and $25 \mathrm{~cm}$ length group, the present findings support these views. 
From present study it could be seen that, in the spawning ground areas (Monpura and Hatia) more than $85 \%$ fishes are above $35.0 \mathrm{~cm}$ sizes, which are breeder group of hilsa. Rahman et al., (2013) also found more than $95 \%$ hilsa in these areas were above $32 \mathrm{~cm}$ in size. Present studies also reconfirm these areas was major spawning grounds of hilsa.

\section{The percent composition of oozing/berried hilsa}

In the spawning grounds, hilsa fishes were found with higher maturity stages/berried (maturity stages IV, $\mathrm{V}$ and $\mathrm{VI}$ ) than the other adjacent areas and percent of the mature hilsa were found higher with the higher length group of fishes due to fishing ban in the spawning grounds (Table 1). Similarly, plenty of fries and juveniles of other fishes were also found in and around the spawning ground areas indicating a positive impact of fishing ban on their successful reproduction. Rahman et al., (2013) found higher maturity stages/berried (maturity stages $\mathrm{V}$ and $\mathrm{VI}$ ) in the breeding areas and percent of the mature hilsa were found higher with the higher length group of fishes. The present study agreed with the findings of Rahman et al., (2013).

Table 1. Maturity stages of hilsa at different length group

\begin{tabular}{|ccccccc|}
\hline Length & \multicolumn{5}{c|}{ Percent of hilsa at maturity stages (Ms) } \\
\cline { 2 - 7 } group & Ms I & Ms II & Ms III & Ms IV & Ms V & Ms VI \\
\hline $18-24$ & 0.00 & 0.00 & 60.00 & 20.00 & 20.00 & 0.00 \\
$25-31$ & 0.00 & 7.78 & 19.85 & 37.21 & 29.20 & 5.96 \\
$32-38$ & 0.00 & 0.00 & 7.38 & 31.84 & 32.68 & 28.10 \\
$39-45$ & 0.00 & 6.90 & 0.00 & 20.75 & 65.25 & 7.10 \\
$46-52$ & 0.00 & 0.00 & 0.00 & 17.65 & 82.35 & 0.00 \\
\hline
\end{tabular}

\section{Percent composition of spent hilsa and spawning success}

Catch composition obtained from the major spawning grounds revealed that more than $90 \%$ captured hilsa weighing around 900 gm were gravid. In the year 2010, 2011, 2012, 2013, 2014 and 2015 about 33.69\%, $36.27 \%, 35.79 \%, 41.02 \%, 38.79 \%$ and $36.6 \%$, respectively spent hilsa was observed in the fish landing centers and this data was compared to the data of GEF-BFRI studies (Haldar, 2004) and was found about $67.38,72.54,71.58,82.04$ and 77.58 times higher than that of 2002. Rahman et al.,(2013) found more than $95 \%$ captured hilsa weighing around $1.0 \mathrm{~kg}$ were gravid and about $5 \%$ spent hilsa. The comparative study showed that 15 days fishing ban during spawning seasons might have significant role in the successful reproduction of hilsa.

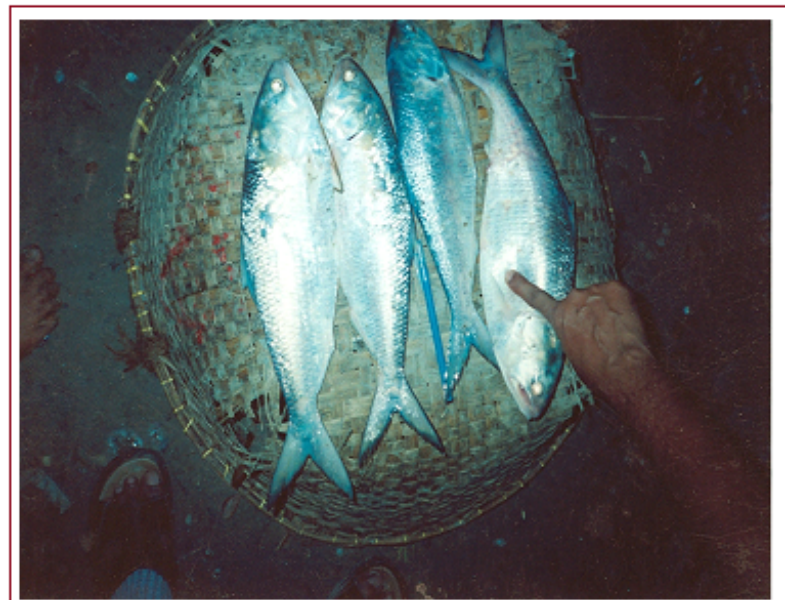

Figure 1. Pictorial view of spent hilsa

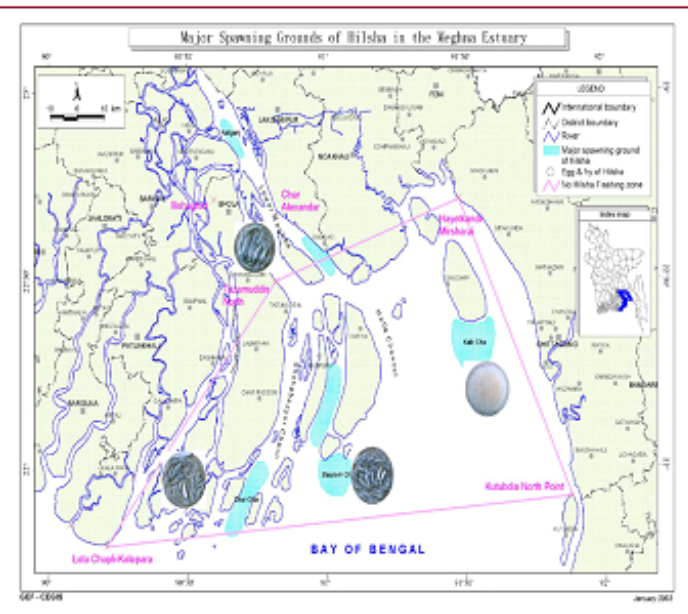

Figure 2. Major spawning grounds of hilsa 


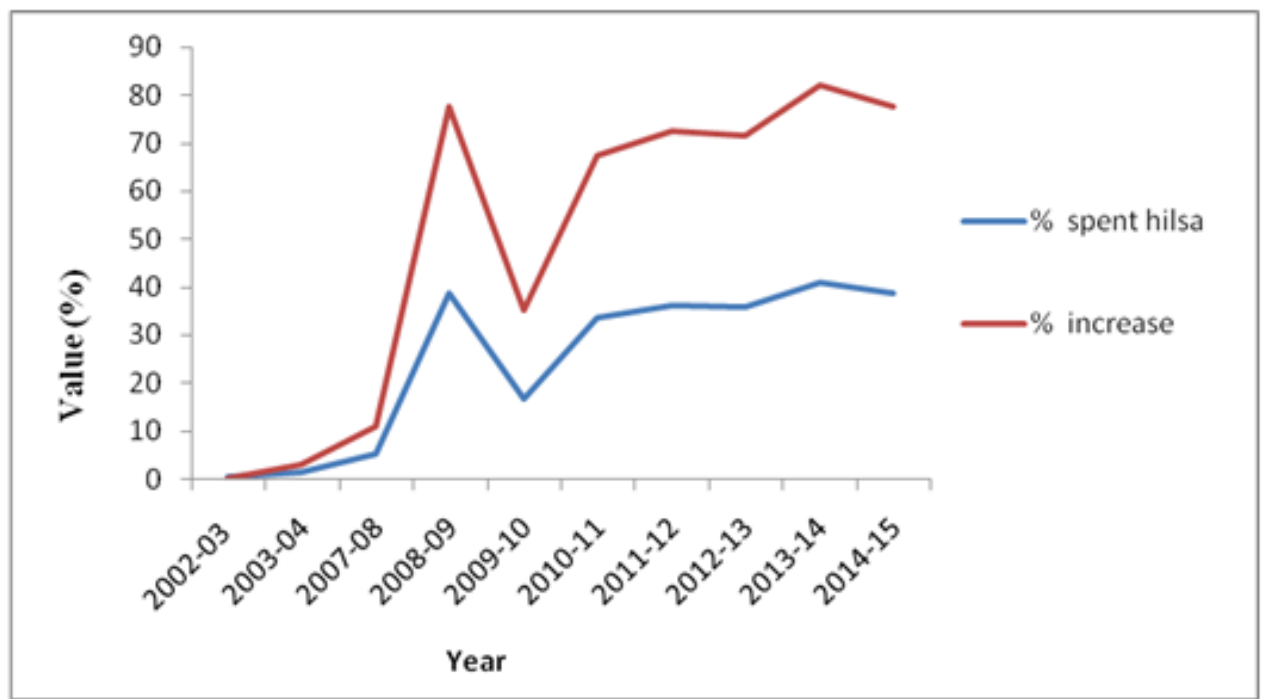

Figure 3. Year wise percentage of spent hilsa. Rahman et al., (2008 and 2013)

\section{Egg/fry production during fishing ban}

Present study showed that in the year 2010, 2011, 2012, 2013, 2014 and 2015 hilsa eggs were produced about $336199 \mathrm{Kg}, 385500 \mathrm{Kg}, 380400 \mathrm{Kg}, 447100 \mathrm{Kg}, 417765 \mathrm{Kg}$ and $494365 \mathrm{Kg}$, respectively due to imposing of 15 days fishing ban in spawning season (Table 2). Rahman et al., (2013) found about 46,800 Kg eggs were produced due to imposing of 10 days fishing ban in spawning season in 2007. So, the present study showed the increasing trend. Rahman et al., (2013) found during experimental spawn and juveniles collection, approximately 5-25 days old fries were found in all the surveyed areas in and around the spawning grounds. Present study also showed the similar trend of result (Table 3).

Table 2. Eggs and jatka Production of hilsa in the major spawning grounds. Rahman et al., (2008 and 2013)

\begin{tabular}{|cccc|}
\hline Year & $\begin{array}{c}\text { Egg production } \\
\mathbf{( k g )}\end{array}$ & $\begin{array}{c}\text { No of fries (crore) } \\
\mathbf{( 5 0 \%} \text { hatching) }\end{array}$ & $\begin{array}{c}\text { Production of jatka } \\
\text { (crore) } \mathbf{( 1 0 \%} \text { survival) }\end{array}$ \\
\hline 2008 & $3,92,620$ & $2,45,385$ & 24,538 \\
2009 & $1,70,420$ & $1,06,512$ & 10,651 \\
2010 & $3,36,199$ & $2,10,124$ & 21,012 \\
2011 & $3,85,500$ & $2,40,937$ & 24,094 \\
2012 & $3,80,400$ & $2,37,750$ & 23,775 \\
2013 & $4,47,100$ & $2,79,437$ & 27,943 \\
2014 & $4,17,765$ & $2,61,103$ & 26,110 \\
2015 & $4,94,365$ & $3,08,978$ & 30,897 \\
\hline
\end{tabular}

Due to impose of 15 days fishing ban in the spawning grounds, comparatively higher percentage of gravid hilsa were found which were not available in the similar quantity and condition in the previous years, i.e. during fishing ban period (Table 4). Rahman et al., (2013) found also the same result.

Haldar (2004) found complete fishing ban has a strong positive impact on jatka abundance. Similarly, Rahman et al., (2013) found jatka abundance increase $570 \%$ by 10 days fishing ban. Present study found that the number of jatka fries (50\% hatching) in the year 2010, 2011, 2012, 2013, 2014 and 2015 were 2,10,124, 2,40,937, 237750, 2,79,437, 2,61,103 and 3,08,978 crore (Table 2), respectively. Rahman et al., (2013) found huge number of fries and juveniles of hilsa by 10 days fishing ban. 
Table 3. Size, weight and age of captured fries and jatka from the major spawning grounds

\begin{tabular}{|c|c|c|c|c|c|c|c|c|}
\hline Location & $\begin{array}{l}\text { Lowest } \\
\text { size } \\
(\mathrm{cm})\end{array}$ & $\begin{array}{l}\text { Highest } \\
\text { size } \\
(\mathrm{cm})\end{array}$ & $\begin{array}{l}\text { Avera } \\
\text { ge size } \\
(\mathrm{cm})\end{array}$ & $\begin{array}{l}\text { Minimum } \\
\text { weight } \\
\text { (g) }\end{array}$ & $\begin{array}{l}\text { Maximu } \\
\text { m weight } \\
\text { (g) }\end{array}$ & $\begin{array}{l}\text { Average } \\
\text { weight } \\
\text { (g) }\end{array}$ & $\begin{array}{l}\text { No. of } \\
\text { jatka/haul }\end{array}$ & $\begin{array}{l}\text { Approx. } \\
\text { age } \\
\text { (day) }\end{array}$ \\
\hline Ramneaz & 1.57 & 2.55 & 1.85 & 0.01 & 0.14 & 0.07 & 22 & $10-15$ \\
\hline Sakuchia & 0.95 & 3.40 & 2.12 & 0.04 & 0.46 & 0.13 & 32 & $5-10$ \\
\hline Janata $\left(\mathrm{ht}^{\star}\right)$ & 1.85 & 3.60 & 2.70 & 0.07 & 0.55 & 0.22 & 47 & $15-25$ \\
\hline Janata $\left(\mathrm{It}^{\star *}\right)$ & 1.80 & 3.50 & 2.65 & 0.05 & 0.54 & 0.19 & 31 & $15-20$ \\
\hline Hazirhat $\left(\mathrm{ht}^{\star}\right)$ & 1.67 & 3.80 & 2.62 & 0.04 & 0.57 & 0.15 & 58 & $15-20$ \\
\hline Hazirhat(It*) & 1.65 & 3.60 & 2.60 & 0.04 & 0.45 & 0.16 & 55 & $15-20$ \\
\hline Dhalchar & 2.20 & 2.9 & 2.60 & 0.13 & 0.30 & 0.15 & 46 & $20-25$ \\
\hline Noyar hat & 1.7 & 4.2 & 3 & 0.20 & 0.66 & 0.28 & 60 & $15-20$ \\
\hline Horina & 1.5 & 2.8 & 2.1 & 0.05 & 0.50 & 0.20 & 24 & $15-20$ \\
\hline Dhulkhola & 1.66 & 3.6 & 2.8 & 0.06 & 0.55 & 0.18 & 38 & $15-20$ \\
\hline
\end{tabular}

$\mathrm{ht}^{*}-$ high tide, $\mathrm{It}^{\star *}-$ low tide

Table 4. CPUE of jatka and management strategy in the major spawning grounds (Rahman et al., 2008 and 2013)

\begin{tabular}{|ccc|}
\hline Year & Caught jatka/100 $\mathbf{~ n e t / h o u r ~ ( K g ) ~}$ & Comment \\
\hline 2002 & 0.94 & Sanctuary \\
2005 & 0.94 & Sanctuary \\
2006 & 0.61 & Sanctuary \\
2007 & 0.72 & Sanctuary \\
2008 & 1.89 & Sanctuary + 10 days Ban \\
2009 & 2.31 & Sanctuary + 10 days Ban \\
2010 & 2.44 & Sanctuary + 10 days Ban \\
2011 & 2.72 & Sanctuary + 11 days Ban \\
2012 & 2.74 & Do \\
2013 & 2.77 & Do \\
2014 & 3.04 & Do \\
2015 & 3.07 & Sanctuary+ 15 days Ban \\
\hline
\end{tabular}

Most of the fishers refrained from fishing during the ban period in the ban areas. Jatka fry, fries of other fishes were also found plentiful in the spawning grounds and adjacent areas and thus it is assumed that fishing ban have some positive impact on the successful breeding of other fishes. Rahman et al., (2008 and 2013) also found same observations.

\section{CONCLUSION}

To sustain as well as to increase hilsa production several management measures have been undertaken by the Ministry of Fisheries and Livestock based on the previous research findings and recommendations. Among the different attempts, conservation of jatka through declaring five fish sanctuaries in the major nursery and spawning grounds of river system and protection of berried hilsa catches for 15 days during the peak breeding season are the most important initiatives. The fishing ban was found effective for successful breeding of hilsa. The impact of 15 days fishing ban on breeding success of other fishes needs to be assessed. The fishing ban should be continued for sustainable reproduction of hilsa and increase of jatka as well as hilsa production. 


\section{REFERENCES}

1. Al-Baz, AF and DJ Grove, 1995. Population biology of Sbour Tenualosa ilisha (Hamilton-Buchanan) in Kuwait. Asian Fisheries Science, 8: 239-254.

2. Blaber, S. J. M. 2000. Tropical estuarine fishes. Ecology, exploitation and conservation, Blackwell, Oxford, 372 pp.

3. Blaber SJM, DA Milton, DT Brewer and JP Salini, 2001. The shads (genus Tenualosa) of tropical Asia: An overview of their biology, status and fisheries. In: Proc., international Terubok. Conf. Sarawark Development Institute (SDI), Kuching, Sarawark, P. 9-17.

4. Fisher W and G Bianchi (Eds.), 1984. FAO species identification sheet for fishes. Vol.1, Tenualosa ilisha (Clupeidae). Food and Agricultural Organization of the United Nations, Rome, Italy.

5. Haldar GC, M Rahman and AKY Haroon, 1992. Hilsa, Tenualosa ilisha (Hamilton) Fishery of Feni River with reference to the impacts of the flood control structures. Journal of Zoology, 7: 51-56.

6. Haldar GC and MA Rahman, 1998. Ecology of Hilsa, Tenualosa ilisha (Hamilton). In: Proceedings of BFRI/ACIAR/CSIRO Workshop on Hilsa Fisheries Research in Bangladesh, held on 3-4 March 1998 at Bangladesh Agricultural Research Council, Dhaka, Bangladesh (edited by M.A. Mazid and S.J.M. Blaber). BFRI proc. No. -6: 86pp.

7. Haldar GC, 2004. Present status of the hilsa fisheries in Bangladesh: Report on hilsa management and conservation studies conducted under the ARDMCS, GEF component, FFP, $70 \mathrm{pp}$.

8. Haldar GC, 2008. Hilsa Fisheries Conservation, Development and Management Technique. 40pp.

9. Hamilton F, 1822. An account of the fishes found in the river Ganges and its branches. Edinburgh \& London. An account of the fishes found in the river Ganges and its branches. : I-VII + 1-405, PIs. 139.

10. Islam MS, Haq QM, Hossain M, Azad SA and NN Das, 1987. Hilsa fishery in Bangladesh in 19851986. Hilsa Investigations in Bangladesh. FAO-UNDP Proj. Mar.Fish.Resour. Manage. Bay of Bengal, Colombo, Sri Lanka. BOBP/Rep/36, 81-95 Rahman et al.

11. Rahman MA, BMS Rahman, SJ Hasan, Flura, T Ahmed and MI Haidar, 2013. Impact of Eleven Days Fishing Ban in the Major Spawning Grounds of Hilsa (Tenualosa ilisha) (Hamilton) on its Breeding Success. Bangladesh Research Publications Journal, 9: 116-122.

12. Quereshi MR, 1968. Hilsa Fishery in East Pakistan. Pakistan Journal of Science and Industry Research. 11: 95-103pp

13. Rahman MA, MA Alam, KKU Ahmed, T Ahmed and GC Haldar, 2008. Assessment of Impact of Ten days Fishing Ban in the Major Spawning Grounds of Hilsa (Tenualosa ilisha) Fisher and Bianchi, 1984). Bangladesh Journal of Fisheries Research, 13: 27-33

14. Raja BTA, 1985. A review of the biology and fisheries of Hilsa ilisha in the Bay of Bengal. Bay of Bengal Programme, BOBP/WP/37. Marine Fishery Resource Management in the Bay of Bengal, 66 pp

15. Shafi M, MMA Quddus and N Islam, 1976. Maturation, spawning, sex-ratio and fecundity of Hilsa ilisha (Hamilton-Buchanan) of the river Padma. Proc. First Bangladesh Science Conference Abstracts: B-45.

16. Whitehead PJP, 1985. FAO Species Catalogue 7, Clupeids fishes of the World. Part I Chirocentridae, Clupeidae and Pristigasteridae. FAO Fisheries Synopsis 125, Volume 7, Part 1, 303 pp. 